\title{
TEACHING ENGLISH INTONATION TO VIETNAMESE STUDENTS OF ENGLISH: TONICITY AND TONE
}

\author{
Ngo Phuong Anh* \\ Hanoi University of Science and Technology, Dai Co Viet, Hai Ba Trung, Hanoi, Vietnam
}

Received 21 April 2017

Revised 23 October 2017; Accepted 23 November 2017

\begin{abstract}
English intonation is often regarded as difficult to teach in the foreign language classroom. However, its communicative value is of importance, with tonicity (nucleus placement / focus) singled out as one of the few prosodic features of the Lingua Franca Core (Jenkins, 2000). This study adopts an experimental approach to investigate the effects of intonation training among Vietnamese learners of English in tertiary education in Vietnam, looking at tonicity and tone. 27 second-year English major students at a Vietnamese university were recruited. Participants were split into the experimental group $(E G, n=16)$ and the control group $(C G, n=11)$. The research was implemented in an intonation training course of ten 150-minute classes taken by the EG, each class consisting of group discussion and intonation training. Quantitative data were collected from EG and CG on their ability to perceive and produce intonation focus and tonal differences in English using intonation pre-tests and post-tests. The results reveal a statistically significant difference in performance between EG and CG in perception and production of tonicity and tone. EG performed better in perception than production and in tonicity than in tone, and performance improved significantly over the period of training.
\end{abstract}

Keywords: English intonation, tonicity, tone, Vietnamese learners

\section{Introduction}

While some mainstream research on pronunciation teaching holds that intonation is, at best, difficult to teach (Chun, 1998; Roach, 2009; Taylor, 1993), others indicate that intonation can be taught successfully, examples being Goh (1994), McGregor and Sardegna (2014, cited in Derwing and Munro, 2015) and de Bot and Mailfert (1982). However, while there are studies looking at intonation patterns among learners of English as a foreign language (EFL), there is a lack of classroom-based research on intonation teaching and learning, as Derwing and Munro (2015) note. The purpose of this study is to investigate whether intonation training for intermediate Vietnamese EFL learners can be successful.

${ }^{*}$ Tel.: 84-934669729

Email: anh.ngophuong@hust.edu.vn

\section{Intonation in English and in English} language teaching

\subsection{Intonation in English}

Intonation is understood as the rise and fall of the pitch of the voice in spoken language (Tench, 1996). Pitch refers to the perceptual correlate of fundamental frequency, i.e., the continuous variation in the sounds we perceive as a result of changes in the rate of vibration of the vocal folds (Cruttenden, 1997). Pitch is relative in value since each individual's pitch level varies (Cauldwell \& Allen, 1997).

Intonation is also known through the phenomenon called prominence, i.e., one syllable in a given meaning group is made more noticeable than others through variations in speech prosody (pitch, loudness and length). This prominent syllable is referred to variably as the focus, the tonic syllable, or the nucleus / nuclear syllable. Division of a stream of speech into meaning groups 
is known as tonality, with tonicity being the placement of the nucleus in that meaning group, and tone referring to the linguistically significant change in pitch instigated at the nuclear syllable.

The role of intonation in one's speech is of high communicative importance (Setter, Stojanovik, Van Ewijk \& Moreland, 2007); as Halliday (1970) points out, intonation is not only a matter of making oneself understood or having good pronunciation, but a way of expressing different meanings. In social interaction, use of intonation signals turn-taking, i.e., giving the floor to another person (Brazil, 1994). It also functions to mark grammar, emphasis and, as an attitudinal marker, it can reveal the speakers' emotions, such as happiness, surprise, anger, and so on (Clennell, 1997). Jenkins (2000) emphasises that suitable placement of the nuclear syllable to draw the listener's attention to salient items in the stream of speech greatly influences a speaker's success (or intelligibility) in conversations, and includes this aspect as one of very few suprasegmental features in the Lingua Franca Core.

The teaching of intonation in EFL contexts, when attempted, is usually integrated into general pronunciation teaching where the focus is on segmentals, i.e., individual speech sounds. In most cases, intonation is often left out as either the 'Cinderella' of pronunciation teaching (Crystal, 1969, p. vii), a luxury, or a 'problem child' (Dalton \& Seidlhofer, 1994, p. 76). However, since the communicative approach took hold in the 1980s, the pronunciation teaching movement has been diverted from bottom up approaches (i.e., a focus on segments) to top-down ones, where the focus is on prosodic features such as intonation, rhythm, and voice quality (Morley, 1991; Wennerstrom, 1994). The growing trend in favour of intonation or other aspects of speech prosody between the late 1980 s and early 2000s is seen in the works of
Scovel (1988), Clennell (1997), Goh (1994), Levis and Pickering (2004), Pickering (2001) and Wennerstrom (1994).

A review of the available literature has shown that very little research on intonation teaching and learning has been recorded so far, and what has taken place failed to reveal evidence about the teaching of English intonation to speakers in tonal language contexts, such as in East Asia, Africa, or the speakers of tonal Indo-European or South Asian/Indian languages. While the research reported in this paper was carried out on speakers of Vietnamese, the literature survey indicates that there are similar intonation problems among speakers of other tonal languages (e.g., Thai, Chinese, Lao and Burmese) and that intonation teaching is neglected among learners from these language backgrounds (see, e.g., Bell, 1996).

Research on intonation training, such as de Bot and Mailfert (1982), Goh (1994) and McGregor and Sardegna (2014, cited in Derwing and Munro 2015), has signalled that improvement in the intonation competence of EFL learners is possible. Goh's (1994) study of Malaysian upper-secondary classes demonstrates improvement, and proposes that intonation can be systematically taught. McGregor and Sardegna (2014), using an approach which raised learners' linguistic awareness about the features they were learning, demonstrated significant improvements in the intonation of 30 second language (L2) English speakers from different first language (L1) backgrounds trained over a 15-week period in several aspects of pronunciation, intonation being one. Findings from de Bot and Mailfert (1982) reveal that the French and Dutch students in their study made improvement in the perception and production of English intonation, with audiovisual feedback found to be more effective than auditory feedback alone. 


\subsection{Intonation teaching in Vietnam}

Ky (2007) claims that the absence of intonation instruction in university English classes in Vietnam results in obvious linguistic poverty both inside and outside the classroom setting.

Although English was introduced as a subject in Vietnamese schools over 30 years ago, in universities where English is not a major subject, English pronunciation has been neglected in favour of grammar, vocabulary and (more recently) other receptive and productive language skills. According to Nguyen, Ingram and Pensalfini (2008), only knowledge of vocabulary and grammar is needed for the students to pass the national exam for high school graduation. For English majors in the university where this research took place, intonation constitutes about one tenth of the whole pronunciation course, which itself accounts for about $5 \%$ of the curricular content. If pronunciation is found at all, the focus is placed on instructing students to pronounce single words correctly. Griffiths attributes this neglect to 'the lack of clear guidelines and rules available in course books' and 'the fact that isolated exercises once a month do not seem to have much of an effect' (Griffiths, 2010, para. 1). In addition, Vietnamese teachers lack confidence in providing a good model for learners (Griffiths 2010) and believe that the tonal system of Vietnamese makes learning English intonation difficult. Doan (2005) and Ky (2007) attribute the neglect of intonation in Vietnamese universities to three main reasons: the lack of time for intonation teaching in the classroom; the lack of available reference materials and the lack of facilities; and the adherence to traditional methods of testing English, which focus more on written tests and ignore speaking and pronunciation.
Studies which investigate Vietnamese learners' pronunciation do exist (e.g., Ha, 2005; Ngo, 2011), but there is hardly any research conducted concerned with intonation teaching. The only study we have been able to locate is that of Doan (2005), who examined 50 Vietnamese fourth year university students' ability to recognise pitch changes, and to produce and understand intonation. The findings of the study revealed that, although $90 \%$ of the participants had the ability to recognise the existence of pitch changes, most of them were unable to explain the meaning of those changes. The author attributed this to the influence of transferring Vietnamese tones into English intonation (Doan, 2005). In addition, the study showed a great difference in Vietnamese learners' intonation compared with native speakers' intonation. However, Doan's study is not about training Vietnamese learners in intonation, but about examining their existing patterns.

\subsection{Tone and intonation in Vietnamese}

This paper assumes a basic level of knowledge about English intonation (see, e.g., Cruttenden, 1997, for further clarification). However, it is useful to review how tone and intonation operate in Vietnamese, particularly as the difference in the two systems is one of the issues raised by Griffiths (2010).

Vietnamese belongs to the Austro-Asiatic language family, under the group of VietMuong on the Mon-Khmer branch. Lexical contrasts are marked by tonal pitch differences and laryngeal features (Yip, 2002). Like Thai and Chinese but unlike English, each monosyllabic word unit has one lexical tone that restricts the meaning of the syllable, i.e., the same syllable from a segmental point of view conveys different meanings depending on the different tone it bears. For example, the syllable [ta] means a variety of things, as shown in Table 1. 
Table 1. The meaning of the Vietnamese syllable [ta] in the standard northern dialect

\begin{tabular}{|c|c|c|c|}
\hline word & tone & Diacritics & Meaning \\
\hline ta & Level & & me / us \\
tá & Rising (sắc) & $/$ & Twelve \\
tạa & low broken (năng) & $\cdot$ & $100 \mathrm{~kg} /$ weightlifting \\
tã & high broken (ngãa) & $\sim$ & Napkin \\
tåa & Curve (hỏì) & $\sim$ & Diarrhea \\
tà & Falling (huyền) & 1 & Evil \\
\hline
\end{tabular}

Vietnamese can be subdivided into three main dialects corresponding to three major geographical regions of Vietnam including the North, the South and the Centre, among which Hanoi Vietnamese (of the North) is considered the standard dialect.

\section{Aims of the research and research questions}

This study seeks to investigate the effect of English intonation training on the performance of Vietnamese university EFL students. Specifically, it aims to see if students make progress in their intonation tone/tonicity perception and production ability through the training, and if equipping them with explicit, basic knowledge of intonation is useful and effective. The research questions are as follows:

1: Does English intonation training make any significant difference to the tonicity and tone perception and production ability of the participants?

2: What effects do the participants think the training approach has had on their English learning?

\section{Methodology}

\subsection{Context of the study}

The study was conducted at a university in Vietnam which offers tertiary-level English programmes that train students to become teachers or translators/interpreters of English. The languages of instruction are English and Vietnamese. Intonation is found in the pronunciation part of the Speaking I module, taught in the first semester of the first year. The module consists of 8 units (53 lessons) with 7 lessons on intonation, including one class on prominent words (stress and tonicity) and another on falling and rising intonation (tone). This means that intonation is practiced for two hours twenty-five minutes out of 33.75 hours, equal to $6.7 \%$ of the pronunciation module time.

\subsection{Participants}

27 students $($ Male $=6 ;$ Female $=21$ ) agreed to take part in the study. There was also a pilot study consisting of 11 participants, the results of which are not reported here. The participants were second year BA students, 19 to 20 years old at the time of the training. They all started learning English aged 10 or 12, came from the North of Vietnam and had all passed the Speaking I module the previous year. They are considered to be intermediate learners of English.

Based on interview data, in general, the participants were aware of intonation, i.e., they knew about falling and rising tones, which they associated with intonation and had been taught about in Speaking I. They were not aware of the term 'tonic syllable', but knew the term 'prominence'. They thought that intonation was important in English communication and wanted to improve their intonation.

The recruitment of the participants to the study was based on criteria sampling (Dörnyei 2007) in a bid to have a sample that is very similar to the target population in its most important characteristics (e.g., age, education background) as well as more specific features (e.g., L2 learning background, type/amount of L2 instruction received).

A non-treatment control group (CG) was used for comparison with the experimental group (EG) (Dimitrov, 2003; Shadish, Cook \& Campbell, 2002). The current research takes as precedent the study by de Bot and 
Malifert (1982) in which the control group received no intonation training but were administered the same pre-test and post-test as the experimental group.

In the first meeting with students, it was intended that they would be split equally into two groups. However, after discussion, 16 students committed to follow the study in full and were selected as the experimental group $(\mathrm{M}=2, \mathrm{~F}=14)$, the remaining 11 students agreeing to be in the control group $(\mathrm{M}=4, \mathrm{~F}=7)$.

CG participants took the pre-test and posttest at the same time as the EG. EG participants attended an induction session two days before the pre-test, during which the participants were informed of the training schedule, the syllabus and the research instruments. It was made clear that all participants could withdraw from the study at any time. Informed consent was then obtained from all participants according to recognized ethical procedures. The pretest (see below) revealed no significant difference in the tests of homogeneity of variance and no significance difference over tonicity perception, tone perception, tonicity production and tone production among the groups before training began.

\subsection{Materials}

The primary aim of the materials design was training the participants in the skills of perception and production of English tonicity and tones. In addition, participants had opportunities to discuss with each other their learning difficulties, to share learning resources, and to write reflections on the training process.

The choice of tonicity and tone was based firstly on the grammatical sub-approach, or 'Contour' approach (Halliday, 1967), and secondly because, along with tonality, tonicity and tone are introduced widely in varying degrees in EFL textbooks such as Hancock (2012), Hewings (2005), and Wells (2006). In addition, systematic description is available for these aspects of intonation which may support teachers and learners (Cauldwell \& Allen, 1997) should they wish to adopt or adapt the methodology used in this study. These aspects of intonation together create the most thorough picture of English intonation at clause level (Tench, 1996).

The instructions closely followed Wells (2006), which was chosen for several reasons: it conforms to the grammatical approach; it provides systematic intonation practice; and the language used is accessible to the target learners.

Supplementary material from other sources was also used. In training Day 7, the discourse function of intonation was introduced to emphasize the significance of intonation in revealing given and new information in conversation (Brazil, Coulthard \& Johns, 1980). Material from Bradford (1994) was used for this.

Other material was a DVD of recordings taken from a popular American television comedy series, introduced to help the participants practice imitation and gesture, encourage them to learn independently, and help them enjoy their learning (Mills 1999). More recently, McGregor, Zielinski, Meyers and Reed (2015) recommend using TED talks for similar reasons.

We selected three tones for the intonation training - fall, rise and fall-rise - as they were the most commonly referred to in the textbooks available to students and also because they are the tones focused on in Wells (2006); Bolinger (1986) and Brazil (1994) have also recommended that these three be taught. See Wells (2006), Roach (2009) and Cruttenden (1997) for an explanation of the form and function meaning of these tones.

The first author, who had had four years' experience of teaching BA students on this university's programmes at the time the data were collected, acted as the intonation trainer. 
A twelve-week period was chosen as that is about the length of a course in a semester (excluding examination time) at the university. Table 2 summarises the training time-frame.

Table 2. Training time frame for the intonation course

\begin{tabular}{|l|l|l|}
\hline Week(s) & $\begin{array}{l}\text { Groups } \\
\text { involved }\end{array}$ & Activity \\
\hline $\begin{array}{l}\text { Week 1 } \\
\text { (June) }\end{array}$ & EG & $\begin{array}{l}\text { Induction } \\
\text { Interview }\end{array}$ \\
\hline $\begin{array}{l}\text { Week 1 } \\
\text { (June) }\end{array}$ & EG, CG & Pre-test \\
\hline $\begin{array}{l}\text { Weeks 2-5 } \\
\text { (June - July) }\end{array}$ & EG & Training class \\
\hline Week 5 & EG & Mid-test \\
\hline $\begin{array}{l}\text { Weeks 6-11 } \\
\text { (July - August) }\end{array}$ & EG & Training class \\
\hline $\begin{array}{l}\text { Week 12 } \\
\text { (August) }\end{array}$ & EG, CG & $\begin{array}{l}\text { Post-test } \\
\text { Final meeting }\end{array}$ \\
\hline
\end{tabular}

\subsection{Training course}

Training took place in the context of a normal classroom, with 10 weekly training sessions lasting two and a half hours each. Classes typically began with a discussion by the participants in groups followed by the participants revising what they had learnt from the previous lesson. Following this was the teaching of the new lesson with a planned sequence of classroom activities and intonation practice from the course-book. At the end of the lesson there was a summary, with handouts distributed for practice after the class. The rest of the participants' time was spent outside the classroom. During this time, participants were told to learn intonation with homework activities suggested by the trainer, and were free to devise their own learning activities, such as to work with roommates, with nonVietnamese English-speakers, and so on.

Following the design of the syllabus, the lesson plans were designed with the format based on Brown (2000) and Nunan (1991). A mixture of the direct method, the audiolingual method and communicative methods were used, as recommended by Celce-Murcia, Brinton and Goodwin (1996) and Richards and Rodgers (2001). A number of classroom activities were used in each training class with the objective of being as interactive as possible (Rivers 1987), including role-play, play-acting, discussion and group-work. Activities were divided into three types, namely controlled practice, semi-controlled practice and uncontrolled practice, which mapped on to Wells' (2006) practice activities, starting with controlled listening and imitating exercises such as drilling, followed by semicontrolled exercises such as the learners working in pairs to listen to and imitate a short dialogue. Finally, the learners practice with their own conversation with or without the trainer's guidance.

\subsection{The test}

The test consists of two parts: perception and production. For perception, the participants were required to recognise and mark the tone (falling, rising, fallingrising) and the tonic syllable (tonicity) in an utterance spoken with eight different intonation patterns. For this part, the audio file from Wells (2006, p. 246) of the utterance But how do you want to pay for it? was used, as produced by one male and one female British English native speakers in eight different intonation patterns. The same stimuli were used each time the test was taken (pre-test, mid-test and post-test) but were presented in a different order each time. For production, the participants were required to produce the same utterance (But how do you want to pay for it?) with different intonation patterns and to underline the tonic syllable (tonicity) and mark the tones (falling/rising/ falling-rising) with a suitable diacritic. One reason for using the same sentence is because participants were also required to describe the function of the different tonicity and tone patterns they chose, but the description task proved too difficult for them and so is not further covered here. A native British English-speaking phonetician analysed the production data and compared them with the 
first author's analysis. The first author then rated the participants' perception data.

As well as the tests, a further research instrument used here is students' diary reports. These were used to collect qualitative data and to support effective reflection on participants' learning (Pennington, 1992). The reflection serves a twofold purpose: 1) as a tool for encouraging self-awareness and the learner's involvement in the pronunciation improvement process; and 2) for the learner to show what he/she finds the most valuable in the course. After each training session, the participants were asked to write a diary report using a set of reflective points as a guide.

\subsection{Data analysis procedures}

In the studies by Goh (1994) and de Bot and Mailfert (1982), exactly how intonation was assessed was not made clear. In this study, intonation patterns were analysed using the contour approach following mark-up with the notation used in Wells (2006) and O'Connor and Arnold (1973).

Participants' production test recordings were anonymised and assessed twice by the authors. We independently identified/ transcribed the tone and tonic syllable in the spoken utterances of 10 of the participants, using annotation conventions from the contour approach (see below for more information). The main method of analysis was auditory, but we used free software Speech Analyser (http://www-01.sil.org/computing/sa/index. $\mathrm{htm})$ to check the intonation patterns. We do not describe its use further here.

We first identified how many IPs there were in the utterance, then underlined the tonic syllable in each IP and indicated a tone using arrows to the left of the tonic syllable. For example, in utterance 1 (U1) for participant 1 (P1), the intonation was marked as follows by both the trainer and the native judge:

P1U1: But how do you want to pay for it?
This indicates that the participant has produced the utterance as one IP, that the tonic syllable is on pay, and that the tone used is a fall, indicated by the downwards pointing arrow.

In $\mathrm{U} 3$, the intonation was marked as follows:

P1U3: But how do $У \nearrow$ you want // to $\searrow$ pay for it?

This indicated that there are two IPs, indicated by the divider //. There are two tonic syllables, one in each IP, each with different tones.

We then compared each participant's response sheet with our transcription to see if they matched. If, on the sheet, the participant had underlined the word pay for $\mathrm{U} 1$ and marked a falling tone on it as in the bold sentence P1U1 above, the candidate would get three points for correct tonicity description and three more points for correct tone description.

In the case of P1U3 above, the maximum points for correct tone and tonicity are still three points. As there are two IPs each containing a tonic syllable and a tone, each correct marked tone and tonic syllable received 1.5 points. In this way, the description of each utterance is worth 3 points, whether or not it contains one or two IPs. It was kept consistent at three points per utterance in order to aid comparison across participants.

Incorrect identification of the tones and tonicity for any one utterance gives the test taker a mark of zero. In cases where the test taker identified the correct tones without marking the tone in front of the right tonic syllable, but still underlined the correct tonic syllable, 0.5 points was deducted from the result if the utterance consists of two IPs and 1 point was deducted if the utterance consists of one IP. For example, in the following hypothetical mark-up, a participant would receive 2.5 points (assuming the tone was indeed a rise).

Hypothetical: But how do you want to pay for it? $\pi$ 
As the participants produced eight sentences, the highest production score possible in the test was 24 points for tonicity (8x3) and 24 points for tone.

To ensure consistency in evaluating the same data under the same scoring criteria, inter- and intra-rater agreement was calculated by taking the ratio of the number of ratings for which both raters agree to the total number of ratings (Bailey, 1998; Stemler, 2004). Initially, 25\% of the recordings were first transcribed before starting to work with the rest of the recordings. The interrater agreement rate between the two authors was $88 \%$, which was considered high enough to continue. As an additional measure of accuracy, both authors transcribed the whole batch again after three months. Intra-rater agreement between these first and second attempts was $93 \%$ for the first author and 94\% for the second author.

The perception test scoring was carried out by the first author based on the accuracy of the correct choice of the participants in terms of tonicity and tone. This was double-checked by a colleague at the host Vietnamese university. The scoring was similar to that of the production score, i.e., 3 points for correct tone and 3 points for correct tonicity, with 24 being the highest possible score over the eight test phrases. As for the production test, where an utterance contained two IPs, each IP with correct tone/tonicity marked accurately by the participants received 1.5 points respectively. Points were deducted for incorrect answers as in the production test.

Here is $\mathrm{U} 1$ as an example, with the nucleus underlined and tone indicated by P1.

Utterance 1: But how do you want to $\searrow$ pay for it?

According to the answer key, there is one IP in this utterance, and the word 'pay' is identified as the tonic syllable with an underscore and marked as having a falling tone with the downward arrow. This means P1 has correctly identified the tonicity and tone as produced in the utterance, and scored three points for tonicity and three points for tone identification respectively.

The test scores for perception and production were analysed using SPSS 17. Comparison between pre- and post-test scores were made, and also comparison of learning gain.

\section{Results}

\subsection{Quantitative results}

Presentation of the quantitative data is followed by some observations from the qualitative results collected from the diary reports. Between groups comparisons: pre-test. Table 3 presents the descriptive statistics for the pretest results. Scores are rounded to a maximum of two decimal points. The highest possible score in each case is 24 .

Table 3. Comparisons of pre-tests between groups

\begin{tabular}{|l|l|l|r|r|r|r|}
\hline & Group & \multicolumn{1}{|l|}{ Number } & \multicolumn{1}{|l|}{ Mean } & \multicolumn{1}{|l|}{ St. Dev. } & Min score & Max score \\
\hline PreTcyPer & EG & 16 & 4.03 & 4.89 & 0 & 13.50 \\
\hline PreTcyPer & CG & 11 & 3.18 & 5.97 & 0 & 16.50 \\
\hline PreTonPer & EG & 16 & 1.13 & 1.77 & 0 & 5.00 \\
\hline PreTonPer & CG & 11 & 1.09 & 1.92 & 0 & 6.00 \\
\hline PreTcyPro & EG & 16 & 4.00 & 3.67 & 0 & 12.00 \\
\hline PreTcyPro & CG & 11 & 1.64 & 2.06 & 0 & 6.00 \\
\hline PreTonPro & EG & 16 & 4.06 & 3.86 & 0 & 14.00 \\
\hline PreTonPro & CG & 11 & 2.09 & 2.77 & 0 & 8.00 \\
\hline
\end{tabular}


As can be seen in Table 3, the experimental group (EG) outperforms the control group (CG) in all of the conditions. The lowest mark (i.e., the minimum score) for each group in each condition is 0 . Both groups scored their lowest average mark in tone perception. The table also shows that $\mathrm{CG}$ has the lowest mean in comparison with EG in tonicity perception, tonicity production and tone production. The standard deviation of the pre-test results of $\mathrm{CG}$ is lower than EG regarding the production pre-tests, but 1 point higher than EG regarding perception pre-tests.

Levene's test indicated homogeneity of variances across all the pre-tests of all four aspects including perception of tonicity $(p=0.192)$, perception of tone $(p=0.311)$, production of tonicity $(\mathrm{p}=0.158)$ and production of tone $(p=0.619)$. One-way ANOVA indicated that there are no significant differences between the groups where any of pre-test conditions are concerned, as $\mathrm{p}>0.05$ in all cases. We can therefore deduce that the perception and production of tonicity and tone of participants in the groups at the start of the training course are similar.

Between groups comparisons: post-test. Descriptive statistics are presented in Table 4. Once again, the highest possible score is 24 .
Table 4 shows that EG participants outperformed those in $\mathrm{CG}$ on average in all tests. The highest average score for any component is in tonicity perception, in which EG scored 19.3, and CG scored 3.55. The maximum score of 24 was achieved by some EG participants for tonicity and tone perception. CG participants recorded the lowest score of 0 in all conditions; EG participants recorded this score in the tonicity and tone perception conditions.

Levene's test indicated homogeneity of variances in Posttnc only $(\mathrm{p}=0.081)$. One-way ANOVA with a Post hoc LSD (Least Significant Difference) test revealed the scores of EG differ significantly from the $\mathrm{CG}$ scores in all conditions. Tonicity perception, tone perception and tone production were very highly significantly different $(p<0.000)$, and tonicity production was highly significant $(\mathrm{p}<0.01)$.

In summary, looking at both the descriptive and the inferential statistics, the training has enabled the experimental group to considerably outperform the control group in all conditions.

Comparisons of the difference (Gain) between the post-test and pretest. Table 5 shows descriptive statistics of any learning gain, with the possible maximum score at 24 .

Table 4. Comparisons of post-tests between groups

\begin{tabular}{|c|c|c|c|c|c|c|}
\hline & Group & Number & Mean & St. Dev. & Min score & Max score \\
\hline PosTcyPer & EG & 16 & 19.31 & 3.60 & 9.00 & 24.00 \\
\hline PosTcyPer & $\mathrm{CG}$ & 11 & 3.55 & 3.75 & 0 & 10.50 \\
\hline PosTonPer & EG & 16 & 13.69 & 5.41 & 3.00 & 24.00 \\
\hline PosTonPer & $\mathrm{CG}$ & 11 & 1.81 & 1.33 & 0 & 3.00 \\
\hline PosTcyPro & EG & 16 & 8.41 & 5.37 & 0 & 19.00 \\
\hline PosTcyPro & $\mathrm{CG}$ & 11 & 1.32 & 1.45 & 0 & 4.50 \\
\hline PosTonPro & EG & 16 & 8.13 & 3.55 & 0 & 14.00 \\
\hline PosTonPro & $\mathrm{CG}$ & 11 & 1.68 & 2.35 & 0 & 6.00 \\
\hline
\end{tabular}


Table 5. Comparisons of gain between groups

\begin{tabular}{|l|l|r|r|r|r|r|}
\hline & Group & \multicolumn{1}{|l|}{ Number } & \multicolumn{1}{|l|}{ Mean } & \multicolumn{1}{l|}{ St. Dev. } & \multicolumn{1}{l|}{ Min score } & \multicolumn{1}{l|}{ Max score } \\
\hline GaiTcyPer & EG & 16 & 15.28 & 5.52 & 6.00 & 24.00 \\
\hline GaiTcyPer & CG & 11 & 0.36 & 6.17 & -13.50 & 7.50 \\
\hline GaiTonPer & EG & 16 & 12.56 & 5.09 & 3.00 & 24.00 \\
\hline GaiTonPer & CG & 11 & 0.09 & 2.21 & -5.00 & 3.00 \\
\hline GaiTcyPro & EG & 16 & 4.41 & 6.38 & -6.00 & 14.00 \\
\hline GaiTcyPro & CG & 11 & -0.32 & 2.59 & -4.00 & 4.50 \\
\hline GaiTonPro & EG & 16 & 4.06 & 4.43 & -1.5 & 12.00 \\
\hline GaiTonPro & CG & 11 & -0.41 & 1.66 & -3.00 & 2.00 \\
\hline
\end{tabular}

EG performed better than CG in all four aspects. The tonicity perception gain has the highest gain mean value overall, in which EG gained 15.28 and the control group gained 0.36 . The maximum score of 24 points is seen in EG in tonicity perception and tone perception condition whereas CG had no maximum gain. The minimum gain is minus for $C G$ in all conditions while the EG had the minus gain (i.e., no gain) in tonicity production and tone production only.

Levene's test indicated no homogeneity of variances in only GaiTcyPer ( $\mathrm{p}=0.980$ ), with all other conditions at $p=<0.05$. ANOVA with a post-hoc LSD test indicates that, in terms of tonicity perception and tone perception, EG's scores are very highly significantly different from $C G(p=0.000)$. For tone perception, there is a highly significant difference $(\mathrm{p}=0.01)$. For tonicity production there is no statistically significant difference $(\mathrm{p}=0.076)$.

Within group comparison. The figures which follow show a comparison of the test scores for EG in tonicity and tone, and include the mid-test taken by participants at the midpoint of the training. Statistically significant differences between test scores are indicated with asterisks for within-feature comparisons and letters for across-feature comparisons, as follows: significance at $\mathrm{p}<0.05$ is indicated with * or $a$, and at $\mathrm{p}<0.001$ with $* *$ or $b$. Performance across features is only looked at for tests taken at the same time, i.e., both pretests, both mid-tests, or both post-tests.

The statistical comparison scores are derived from paired sample t-tests. Firstly, the perception of tonicity and tone is examined, followed by the production of tonicity and tone.

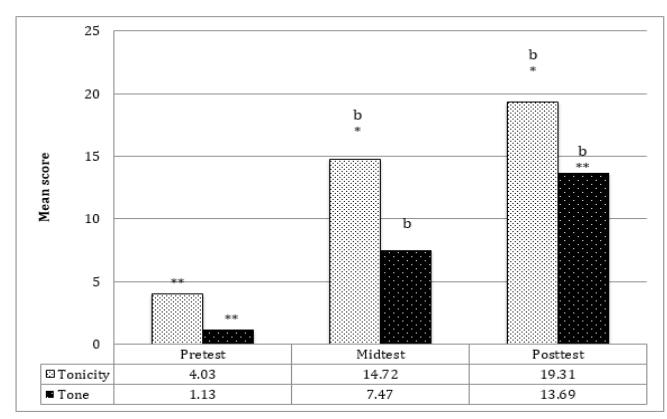

Figure 1. Perception score comparison within the experimental group

Looking at the asterisked items, Figure 1 shows that there is improvement in EG regarding perception of tonicity and tone. The improvement is consistent across the pre-, mid- and post-tests. For tonicity perception, the difference in score is significantly different between the pre- and mid-tests $(p<0.001)$, the pre- and post-tests $(\mathrm{p}<0.001)$ and the mid- and post-test $(\mathrm{p}<0.01)$; i.e., there is less difference between the mid- and post-test scores but it is still highly significant. For tone perception, the difference between all test scores is very highly significantly different at $\mathrm{p}<0.001$ for each comparison (pre- and mid-test, mid- and 
post-test and pre- and post-test). Turning to the items marked with letters, i.e., the across feature comparisons, significance is found between the scores for the tonicity and tone perception mid-tests $(\mathrm{p}<0.001)$ and between tonicity and tone perception post-tests ( $p=0.000$ ), but not between the pre-tests. This shows that performance was significantly better in tonicity perception than in tone perception, even though improvement is seen in both conditions.

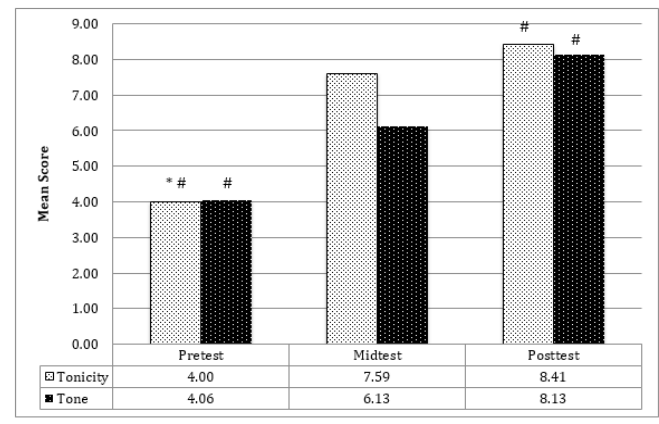

Figure 2. Production score comparison within the experimental group

A similar pattern of improvement emerges in the production tests of tonicity and tone, i.e., a consistent improvement is seen across the pre-, mid- and post-tests, as shown in Figure 2. In the production of tonicity (light grey bars), there is significant difference between the pre- and mid-tests $(p<0.01$, indicated with $*$ ) and the pre- and post-tests ( $\mathrm{p}<0.01$, indicated with '\#'; the hash symbol is used here to disambiguate between the two). Concerning tone (dark grey bars), there is a significant difference between the pre- and post-tests only $(\mathrm{p}<0.01$, indicated with a hash symbol). No significant difference is found in test scores across features of tonicity and tone. It is also worth noting here that, although production improvement is shown in each of the categories, it is less than the improvement in perception in that the scores are generally much lower.

There were no statistically significant differences in the CG data.

\subsection{Qualitative results}

We now turn to the participants' diaries to answer research question 2 on their perceived effect of the training course on their learning. Results indicate a positive perceived impact of the training overall. Noteworthy is the positive change the training brought about in the participants' understanding of intonation (75\% of the EG, i.e., 12 participants, commented on this), and the raising of awareness of intonation in speech $(n=1,6 \%)$. Three examples follow (roughly translated from Vietnamese by the paper's author).

In the past, my awareness of intonation was nothing, but this is changed at this point. I always think that we have to use rising tone for yes/no question and falling for wh-question. After completing the session, I realized that what I thought was not true. (P13D1)

My knowledge about intonation and pronunciation was broadened. (P7D1) I thought in tag questions, I should always raise my voice at the end of a sentence to express that my partner would agree with me. However, I was wrong. Moreover, I saw that I use a rise or a fall for the tag question to express my different idea. In addition, independent elliptical questions are not so difficult. (P7D2)

Although this is only a small sample of comments, to some extent they refute Dalton and Seidlhofer's (1994) assertion that learning aspects of English intonation is difficult.

There were also comments about the positive effects that certain strategies adopted by the participants had had on their learning. Students were given a list of suggested strategies, some of which they had not tried before.

The language learning strategies list [we were given] is very helpful. I learnt very much from the list. Some of the strategies I used before but many are new. (17D10) 
One participant commented on imitation as a strategy:

After the training, I realize that intonation is so interesting and previously, I didn't want to imitate anyone, but now, I really want to imitate the native speakers. They speak so beautifully (P7D9).

Another commented on the usefulness of rote learning of words and phrases:

It is very interesting to learn tones by learning by heart the words 'congratulation', 'monkey' and 'what a voice'. (P3D10)

In addition, $18 \%(n=3)$ reported on the positive effect of having opportunities to discuss and share learning strategies and experiences, and $18 \%(n=3)$ reported they had become more active and motivated to learn English intonation.

Lastly to add to the effects of the training is the participants' awareness of the importance of intonation. While only $18 \%$ of the participants wrote in their diary that they supported intonation being an independent subject at university, in the final meeting in Week $12,100 \%(n=16)$ of the participants said that intonation should be integrated into their degree programme as a separate module. This suggestion supports Jeidani (2012) and Goh (1994), which report that Syrian and Malaysian learners respectively are in favour of intonation being taught. Finally, all of the participants in this study said that, following the training, they realised intonation was more important in communication and in English learning than they had thought, and that the subject was equally as important as other English language skills.

\section{Discussion}

While only a small number of participants took part in this research, the above results demonstrate that training in intonation perception and production can lead to significant improvement among Vietnamese EFL learners, both in comparison with a control group and in terms of their improvement across the three tests points. This, therefore, makes a valuable contribution to the study of L2 English intonation learning and teaching in tonal L1 environments. The results also indicate that intonation is neither unteachable, as asserted in Taylor (1993), too difficult to learn, as Dalton and Seidlhofer (2004) suggested, nor indeed perceived as too difficult to learn. Quantitative data further indicate that participants felt they benefitted from learning more about intonation, enjoyed developing their intonation skills and trying out new strategies for doing so, and that, if they had their way, there would be more of it on the curriculum.

Participants in both groups performed better at tonicity than tone, and perception scores are higher than the production scores. Tonicity scoring higher than tone is a positive finding in light of Jenkins' (2000) assertion that nuclear stress (tonicity) is important for intelligibility and should, therefore, be part of the Lingua Franca Core, unlike tone. It is also generally predictable from the literature that improvement in perception will be better than in production (e.g., Brazil et al, 1980; Roach, 2009). The results further support those of of Goh (1994), de Bot and Mailfert (1981) and McGregor and Sardegna (2014), showing that intonation perception ability can be improved after short-term training, and that intonation perception improvement was accompanied by improvement in production. Although it is not clear if improved perception leads to improved production, as suggested by de Bot and Mailfert (1982), as we know that perception precedes production in typical first language acquisition, and that some early experimental approaches to English language teaching have been predicated on this - see, e.g., Asher 
(1966) and Gattegno (1971) - it can be hoped that improved perception will pave the way to increasingly improved production.

One negative issue to report here is that, although the participants in the EG were able to develop skills in producing and perceiving suitable tonicity and tonal patterns, they did not succeed in explaining the differences in meaning in patterns they generated themselves, resulting in an abandonment of this part of the research. Their inability could be because they did not understand the difference in meaning. An alternative explanation, however, is that they simply had not developed the metalanguage, either in Vietnamese or English, to explain what different patterns mean, or were not confident in using it. We would therefore recommend that, should intonation be taught as a much larger component of any English language provision, there be a greater focus on equipping learners with the means to articulate the difference in meaning relayed by manipulating tonicity and tone, so that they may better understand how to use it.

\section{References}

\section{Vietnamese}

Nguyễn Huy Kỷ (2007). Ngữ điệu tiếng Anh ở người

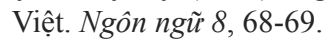

Đỗ Tiến Thắng (2008). Ngũ điệu tiếng Việt sơ thảo [Introduction to Vietnamese intonation]. Hà Nội: NXB ĐH Quốc gia Hà Nội.

\section{English}

Asher, J. J. (1966). The Learning Strategy of the Total Physical Response: A Review. The modern language journal, 50(2), 79-84. doi: 10.1111/j.15404781.1966.tb03573

Bailey, K. M. (1998). Learning about language assessment: Dilemmas, decisions, and directions. Pacific Grove, CA: Heinle \& Heinle Publishers.

Bell, M. (1996). Teaching pronunciation and intonation to EFL learners in Korea. Retrieved Dec, 6, 2009, from http://www.reocities.com/Athens/ acropolis/9583/PRONUN.html

Bolinger, D. (1986). Intonation and its parts. Palo Alto: Stanford University Press.
Bradford, B. (1994). Intonation in Context. Cambridge: Cambridge University Press.

Brazil, D. (1994). Pronunciation for Advanced Learners of English: Student's book. Cambridge: Cambridge University Press.

Brazil, D., Coulthard, M., \& Johns, C. (1980). Discourse Intonation and Language Teaching. Harlow: Longman.

Brown, H. D. (2000). Principles of language teaching and learning. $4^{\text {th }}$ edition. New York: Longman.

Cauldwell, R., \& Allen, M. (1997). Phonology. Birmingham: The University of Birmingham.

Celce-Murcia, M., Brinton, D., \& Goodwin, J. M. (1996). Teaching pronunciation: A reference for teachers of English to speakers of other languages. Cambridge: Cambridge University Press.

Chun, D. M. (1998). Signal analysis software for teaching discourse intonation. Language Learning and Technology 2(1), 61-77.

Clennell, C. (1997). Raising the pedagogic status of discourse intonation teaching. ELT Journal, 51(2), 117-125. doi: 10.1093/elt/51.2.117

Cruttenden, A. (1997). Intonation ( $2^{\text {nd }}$ ed.). Cambridge: Cambridge University Press.

Crystal, D. (1969). Prosodic systems and intonation in English ( $1^{\text {st }}$ ed.). Cambridge: Cambridge University Press.

Dalton, C., \& Seidlhofer, B. (1994). Pronunciation: Oxford: Oxford University Press.

de Bot, K. (1981). Intonation teaching and pitch control. ITL Review of Applied Linguistics, 52, 31-42.

de Bot, K., \& Mailfert, K. (1982). The teaching of intonation: Fundamental research and classroom applications. TESOL Quarterly, 16(1), 71-77. doi: $10.2307 / 3586564$

Derwing, T. M. \& Munro, M. J. (2015). Pronunciation Fundamentals: Evidence-based Perspectives for L2 teaching and research. Amsterdam: John Benjamins. doi: $\underline{10.1075 / 111 t .42}$

Dimitrov, D. M., \& Rumrill Jr, P. D. (2003). Pretest-posttest designs and measurement of change. Work, 20(2), 159-165.

Đoàn Minh Mão (2005). The awareness and employment of English intonation among ULIS 4th year students of English as first major. Unpublished M.A thesis, Hanoi National University.

Dörnyei, Z. (2007). Research methods in applied linguistics: Quantitative, qualitative, and mixed methodologies. Oxford: Oxford University Press.

Gattegno, C. (1971). Silent Way. Toronto: Educational Solutions Incorporated.

Goh, C. C. M. (1994). Exploring the teaching of discourse intonation. RELC Journal, 25(1), 77-98. Doi: 10.1177/003368829402500104

Griffiths, B. (2010). Integrating pronunciation into classroom activities. Retrieved 1 March, 2011, 
from http://www.teachingenglish.edu.vn/en-US/ Teaching-tips/Integrating-pronunciation-intoclassroom-activities.html

Hà Cẩm Tâm. (2005). Common pronunciation problems of Vietnamese learners of English. VNU Journal of Science: Foreign studies, 21(1), 1-11.

Halliday, M. A. K. (1967). Intonation and grammar in British English. The Hague: Mouton.

Halliday, M. A. K. (1970). A course in spoken English: Intonation. Oxford: Oxford University Press.

Hancock, M. (2003). English pronunciation in use: Intermediate-self-study and classroom use. $2^{\text {nd }}$ edn. Cambridge: Cambridge University Press.

Hewings, M. (2004). Pronunciation practice activities. Cambridge: Cambridge University Press.

Jeidani, M. (2012). Increasing phonological awareness: a discourse intonation approach. Unpublished $\mathrm{PhD}$ thesis, University of Warwick.

Jenkins, J. (2000). The phonology of English as an international language: New models, new norms, new goals. Oxford: Oxford University Press.

Levis, J., \& Pickering, L. (2004). Teaching intonation in discourse using speech visualization technology. System, 32(4), 505-524. http://dx.doi.org/10.1016/j. system.2004.09.009

McGregor, A., Zielinski, B., Meyers, C. \& Reed, M. (2016). An exploration of teaching intonation using a TED Talk. In J. Levis, H. Le., I. Lucic, E. Simpson, \& S.Vo (Eds). Proceedings of the 7th Pronunciation in Second Language Learning and Teaching Conference, ISSN 2380-9566, Dallas, TX, October 2015 (pp. 143-159). Ames, IA: Iowa State University.

McGregor, A., \& Sardegna, V. G., (2014). Pronunciation improvement through an awareness-raising approach. Paper presented at the American Association for Applied Linguistics (AAAL), Portland, Oregon.

Mills, M. R. N. (1999). Developing specific support material to accompany feature films on video for self-access language learning. MA thesis, Bangkok: King Mongkut's University of Technology Thonburi.

Morley, J. (1991). The pronunciation component in teaching English to speakers of other languages. TESOL Quarterly, 25(3), 481-520.

Nguyen, T., Ingram, C., \& Pensalfini, J. R. (2008). Prosodic transfer in Vietnamese acquisition of English contrastive stress patterns. Journal of Phonetics, 36(1), 158-190. http://dx.doi. org/10.1016/j.wocn.2007.09.001

Ngô Phương Anh (2011). L1 influence on Vietnamese accented English. In K. Vincent \& J. F. BoteroGarcia (Eds.), Voices (pp. 108-125). Cambridge: Cambridge Scholar Publishing.

Nunan, D. (1991). Language teaching methodology. New York: Prentice Hall.
O’Connor, J. D., \& Arnold, G. F. (1973). Intonation of colloquial English (2 ${ }^{\text {nd }}$ ed.). London: Longman.

Pennington, M. (Ed.). (1992). Reflecting on teaching and learning: A development focus for the second language classroom. Kowloon: City Polytechnic of Hong Kong.

Pennington, M. C. (1998). Designing language programme evaluation for specific purposes. In E. S. L. Li \& G. James (Eds.), Testing and evaluation in second language education (pp. 179-193). Hongkong: Language Centre, Hongkong University of Science and Technology.

Pickering, L. (2001). The Role of Tone Choice in Improving ITA Communication in the Classroom. TESOL Quarterly, 35(2), 233-255.

Pickering, L. (2004). The structure and function of intonational paragraphs in native and non native instructional discourse. English for specific purposes 23: 19-43. http://dx.doi.org/10.1016/ S0889-4906(03)00020-6

Richards, J.C., \& Rodgers, T.S. (2001). Approaches and Methods in Language Teaching. Cambridge: Cambridge University Press.

Rivers, W. M. (1987). Interactive Language Teaching. New York: Cambridge University Press.

Roach, P. (2009). English phonetics and phonology (4 ${ }^{\text {th }}$ ed.). Cambridge: Cambridge University Press.

Scovel, T. (1988). A time to speak: A psycholinguistic inquiry into the critical period for human speech. Newyork: Newbury House/Harper \& Row.

Setter, J., Stojanovik, V., Van Ewijk, L., \& Moreland, M. (2007). Affective prosody in children with Williams syndrome. Clinical Linguistics \& Phonetics, 21(9), 659-672. doi:10.1080/02699200701539056

Shadish, W. R., Cook, T. D., \& Campbell, D. T. (2002). Experimental and quasi-experimental designs for generalized causal inference. Belmont, CA: Wadsworth Cengage learning.

Stemler, S. E. (2004). A comparison of consensus, consistency, and measurement approaches to estimating interrater reliability. Practical Assessment. Research \& Evaluation, 9(4), 80-89.

Taylor, D. S. (1993). Intonation and accent in English: what teachers need to know. International Review of Applied Linguistics in Language Teaching and Teacher Education, 31(1), 1-22. doi: 10.1515/ iral.1993.31.1.1

Tench, P. (1996). The intonation systems of English. London: Cassell.

Wells, J. C. (2006). English intonation. Cambridge: Cambridge University Press.

Wennerstrom, A. (1994). Intonational meaning in English discourse: A study of non-native speakers. Applied Linguistics, 15(4), 399-420. doi: 10.1093/ applin/15.4.399

Yip, M. (2002). Tone. Cambridge: Cambridge University Press. 


\title{
DẠY NGỮ ĐIỂU TIẾNG ANH CHO SINH VIÊN VIẸT NAM: XÁC ĐỊNH ÂM TIẾT HẠT NHÂN VÀ CÁC KIỄU NGỮ ĐIỆU
}

\author{
Ngô Phương Anh \\ Trường Đại học Bách khoa Hà Nội, Đại Cồ Việt, Hai Bà Trung, Hà Nội, Việt Nam
}

Tóm tắt: Ngữ điệu tiếng Anh được coi là một kỹ năng khó dạy và thường bị bỏ quên trong lớp học ngoại ngữ. Tuy nhiên, nó có giá trị quan trọng đối với hoạt động giao tiếp. Nghiên cứu này áp dụng phương pháp thực nghiệm, điều tra những ảnh hưởng của việc dạy ngữ điệu cho người học tiếng Anh. 27 sinh viên năm thứ hai chuyên ngành tiếng Anh tại một trường đại học Việt Nam đã tham gia một khóa dạy ngữ điệu gồm 10 buổi học, 150 phút/buổi (nhóm thực nghiệm (EG, $\mathrm{n}=$ 16); nhóm đối chứng $(\mathrm{CG}, \mathrm{n}=11)$ ). Mỗi buổi học có các phần thảo luận nhóm và luyện ngữ điệu. Dữ liệu định lượng về khả năng nhận biết và tạo ra các kiểu ngữ điệu được thu thập từ $E G$ và $C G$ qua các bài kiểm tra trước và sau khóa học. Kết quả cho thấy sự khác biệt lớn về hiệu quả giữa $E G$ và $C G$ trong cảm nhận và tạo các kiểu điệu. $E G$ cảm nhận ngữ điệu tốt hơn hơn là tạo ra các kiểu ngữ điệu, hiệu quả rõ hơn ở việc xác định âm tiết hạt nhân.

Tư khoá: ngữ điệu tiếng Anh, âm tiết hạt nhân, kiểu ngữ điệu, người học Việt Nam 